Olfactory neuroblastoma (ONB) is a rare malignant neoplasm of sinonasal tract, derived from olfactory epithelium. Unilateral nasal obstruction, epistaxis, sinusitis, and headaches are common symptoms. Olfactory neuroblastoma shows neuroendocrine differentiation and similarly to other neuroendocrine tumors can produce several types of peptic substances and hormones. Excess production of these substances can be responsible for different types of endocrinological paraneoplastic syndromes (PNS). Moreover, besides endocrinological, in ONB may also occur neurological PNS, caused by immune cross-reactivity between tumor and normal host tissues in the nervous system. Paraneoplastic syndromes in ONB include: syndrome of inappropriate ADH secretion (SIADH), ectopic ACTH syndrome (EAS), humoral hypercalcemia of malignancy (HHM), hypertension due to catecholamine secretion by tumor opsoclonus-myoclonus-ataxia (OMA) and paraneoplastic cerebellar degeneration. Paraneoplastic syndromes in ONB tend to have atypical features, therefore diagnosis may be difficult. In this review, we described initial symptoms, patterns of presentation, treatment and outcome of paraneoplastic syndromes in ONB, reported in the literature.

Key words: olfactory neuroblastoma, paraneoplastic syndromes, vasopressin, catecholamines, ACTH.

Contemp Oncol (Pozn) 2015; 19 (1): 6-16 DOI: $10.5114 /$ wo.2014.46283

\title{
Paraneoplastic syndromes in olfactory neuroblastoma
}

Michał Kunc ${ }^{1}$, Anna Gabrych ${ }^{1}$, Piotr Czapiewski², Krzysztof Sworczak ${ }^{3}$

${ }^{1}$ Medical University of Gdańsk, Poland

${ }^{2}$ Chair and Department of Pathomorphology, Medical University of Gdańsk, Poland ${ }^{3}$ Department of Endocrinology and Internal Diseases, Medical University of Gdańsk, Poland

\section{Introduction}

Olfactory neuroblastoma (ONB) is a rare malignant neuroectodermal tumor, comprising about $2 \%$ of all sinonasal tract tumors. Olfactory neuroblastoma is thought to arise from the specialized sensory neuroectodermal olfactory cells that are normally found in the upper part of the nasal cavity, including the superior nasal concha, the upper part of the septum, the roof of the nose, and the cribriform plate of ethmoid. Olfactory neuroblastoma may occur at any age, but demonstrates a bimodal peak of occurrence in the second and sixth decades of life without specific gender predilection. Unilateral nasal obstruction, epistaxis, sinusitis, and headaches are common symptoms. Delay in diagnosis is very frequent due to benign and nonspecific symptoms [1]. Olfactory neuroblastoma may mimic almost all tumors in the head and neck region, being described by Ogura et al. as a "great impostor" [2]. In one retrospective study, a review of 12 patients who were admitted to a single institute within two years and diagnosed with ONB was performed. After stringent neuropathology review, it turned out that the diagnosis was correct in only one in two patients [3].

Histologically, ONB is composed of small, round, blue cells, with a very high nuclear to cytoplasmic ratio, which are organized in lobules surrounded by sustentacular cells. Hyams' grading system separates tumors into 4 grades. This scale is based on architecture, Flexner-Wintersteiner rosettes, Homer-Wright pseudo-rosettes, calcifications, fibrillar matrix, pleomorphism, necrosis and mitotic activity. However, ONB is often separated into low-grade (Hyams' grade I and II) and high-grade (Hyams' grade III and IV) in order to correlate grade with outcome. Low grade tumors have an $80 \%$ 5-year survival, while high grade tumors have a $40 \%$ survival [4].

The first and most common staging system was developed by Kadish [5]. It divides tumors into 3 groups. In group A, the tumor is limited to the nasal cavity; in group B, the tumor is localized to the nasal cavity and paranasal sinuses; and in group C, the tumor extends beyond the nasal cavity and paranasal sinuses. Morita modified this system, adding a fourth tier (D), which consists of local and distant metastases [6]. Another known classification is the Dulguerov et al. staging system, which is based on the TNM scale [7]. Nevertheless, no single staging classification has been universally adopted for this tumor to date, as the prognostic utility of each system has not been proven $[5,8]$.

Due to rarity of ONB, there are no specific treatment guidelines. However, usually craniofacial resection followed by radiotherapy is used in treatment of primary low- to moderate-grade lesions, with the addition of chemotherapy in patients with advanced, recurrent, or metastatic disease [4].

The main immunohistochemical findings include synaptophysin, chromogranin A, CD56, neuron-specific enolase (NSE), neurofilament proteins (NFP) and S-100 protein, which confirmed neuroendocrine differentiation in ONB [9]. Although most of the neuroendocrine tumors produce and secrete a large number of peptide hormones and amines, which can cause a spe- 
cific clinical syndrome, most ONBs belong to so-called "non-functioning" tumors [10].

Although rare, ONB may be associated with paraneoplastic syndromes (PNS). Signs and symptoms in PNS do not result from direct tumor invasion or compression, but are related to tumor secretion of some peptides and hormones or immune cross-reactivity between tumor and normal host tissues [11]. To our knowledge, in ONB, endocrinological (syndrome of inappropriate ADH secretion - SIADH, ectopic ACTH syndrome - EAS, humoral hypercalcemia of malignancy - HHM, hypertension due to catecholamine secretion by tumor) and neurological PNS (opsoclonus-myoclonus-ataxia - OMA; cerebellar degeneration) may occur. In this review we describe the clinical characteristics of paraneoplastic syndromes reported in the literature, focusing on the diagnostic process and treatment options.

\section{Endocrinological paraneoplastic syndromes}

\section{Ectopic ACTH syndrome}

Ectopic ACTH syndrome is a PNS which can be associated with variety of solid tumors, mostly of neuroendocrine origin. The usual location is the chest, and the most frequent pathologies are small cell lung carcinoma (SCLC) and bronchial carcinoid. Less frequent causal tumors are thymic carcinoids, pancreatic islet cell tumors, pheochromocytomas, paragangliomas and medullary thyroid carcinomas [12].

Paranasal sinuses are not a common location for EAS, although there are a few cases of ACTH-producing tumors that originate from this area [13]. To our knowledge, 18 cases of ACTH-secreting ONBs have been described in the world literature (Table 1).

Ectopic pituitary adenomas are other reported cephalic pathologies associated with Cushing's syndrome (CS). Because of the proximity to the sella, ONBs must be distinguished from pituitary adenomas that have extended downward into the nasal cavity or mentioned intracranial "ectopic" pituitary adenomas which originate from remnant cells deposited along the Rathke's pouch developmental route and may develop into hormonally active adenomas in the ectopic regions, such as the sphenoid or cavernous sinus [14]. ACTH-secreting neuroendocrine tumors such as nasal paragangliomas [15, 16], ACTH-secreting nasopharyngeal carcinoma and meningioma [13] are other described paranasal and cranial ectopic sources of ACTH.

Usually rapid development of symptoms is characteristic of EAS, but not for pituitary adenomas. Weight loss rather than gain, fewer manifestations of cortisol excess, frequent manifestations of mineralocorticoids excess, hyperpigmentation, myopathy and hypokalemic alkalosis tend to be typical features of EAS [1].

There are two main types of EAS. The first is associated with clinically evident malignancies; a classic example of this entity is SCLC. The second type is secondary to a clinically occult neoplasm, with bronchial carcinoid being the classical example. Occult ACTH-secreting tumors frequently present a clinical picture similar to that seen with pi- tuitary-dependent Cushing's disease (CD), whereas overt tumors present atypically, with muscle wasting and weight loss being more frequently observed than the classic signs of hypercortisolism, such as moon face, truncal obesity, purple striae, etc.

The differences between types of EAS may result from molecular features. Carcinoid cells express the POMC gene like pituitary corticotroph cell, transcript pituitary like, 1200-nt, POMC mRNA and process the precursors to release large amounts of bioactive ACTH. In comparison, SCLC processes POMC in an aberrant way, producing low levels and altered molecular forms of POMC RNA, releasing high concentrations of "big ACTH" and less intact ACTH in the circulation [17]. Unfortunately, there are no studies about POMC processing in ACTH-secreting ONBs.

Ectopic ACTH syndrome associated with ONB could not be matched with either the first or the second type. In 9 cases, CS developed simultaneously with ONB diagnosis or its recurrence, in 5 in previously diagnosed evident ONB. However, in 4 cases, the location of the ACTH-secreting tumor was occult (median for interval between first CS symptoms and ONB diagnosis = 18 months). In ONB weight loss was reported in only 1 patient, myopathy in 5 out of 18 , whereas weight gain was noted in 10 out of 18 patients, moon face in 9 out of 18, and red striae and purpura in 7 out of 18. Hypokalemia and metabolic alkalosis, which are more frequently found in both types of EAS than in CD, occurred in 11 out of 18 patients. Olfactory neuroblastoma may present a unique profile of CS manifestation, in which symptoms are rather similar to pituitary-dependent disease, while tumor is often overt [18].

ACTH-secreting ONB is an extremely rare cause of EAS, so one cannot be aware of the existence of this association from the very beginning of the diagnostic process. This diagnosis is very difficult for several reasons. First, despite the fact that the most accurate method of distinguishing between pituitary ACTH secretion and EAS is known to be IPSS, ONB might cause a false positive result more frequently when this method is used. This is a consequence of tumor location in the ethmoid sinus, which adjoins the upstream of the pituitary venous drainage system [19]. Generally, false positive results of IPSS may result from ectopic corticotropin-releasing hormone $(\mathrm{CRH})$ secretion by the tumor, which stimulates ACTH production by the pituitary cells, or when there is a tumor with intermittent ACTH secretion or adrenal tumors with intermittent cortisol production, which could incompletely suppress endogenous ACTH production [20].

The CRH stimulation test and HDDST also help to distinguish EAS from a pituitary adenoma. Corticotropin-releasing hormone stimulation tests give a more accurate result than HDDST; however, among the reported cases of EAS associated with ONB, only a few reported the results of the $\mathrm{CRH}$ stimulation test [21]. One of them, diagnosed as ACTH-secreting ONB, showed increased ACTH levels after $\mathrm{CRH}$ stimulation, which might have led to a misdiagnosis of Cushing's disease. Only $4 \%$ of patients with EAS respond to $\mathrm{CRH}$. However, plasma ACTH and cortisol were non-suppressible to high-dose dexamethasone, but IPSS showed a high central-to-peripheral ratio of ACTH level [19, 
Table 1. Case reports of olfactory neuroblastoma with ectopic ACTH syndrome

\begin{tabular}{|c|c|c|c|c|c|c|}
\hline Study & Age & Sex & Symptoms & Treatment & $\begin{array}{l}\text { Treatment at } \\
\text { relapse }\end{array}$ & Outcome \\
\hline $\begin{array}{l}\text { Reznik } \\
\text { et al. [28] }\end{array}$ & 48 & female & CS 28 months after initial treatment & surgery, chemotherapy & - & DDD \\
\hline $\begin{array}{l}\text { Fish et al. } \\
{[36]}\end{array}$ & 45 & male & $\begin{array}{l}\text { epistaxis, pneumonia, weight loss, lower-extremity } \\
\text { swelling, polyuria, blurred vision, generalized weakness, } \\
\text { hypokalemia, hyperglycemia }\end{array}$ & ketoconazole & - & $\begin{array}{l}\text { lost to follow- } \\
\text { up; }\end{array}$ \\
\hline $\begin{array}{l}\text { Yu et al. } \\
{[26]}\end{array}$ & 36 & male & $\begin{array}{l}\text { hypertension, hyperglycemia, pedal edema, proximal } \\
\text { muscle weakness, mental confusion, hypokalemic } \\
\text { alkalosis, facial plethora, buffalo hump, supraclavicular } \\
\text { fat deposition, central obesity }\end{array}$ & $\begin{array}{l}\text { metyrapone, } \\
\text { radiotherapy }\end{array}$ & - & $\begin{array}{l}\text { CS symptoms } \\
\text { resolved }\end{array}$ \\
\hline $\begin{array}{l}\text { Arnesen } \\
\text { et al. [37] }\end{array}$ & 36 & female & $\begin{array}{l}\text { moon face, hyperglycemia, hypertension, hypokalemia, } \\
\text { central obesity, proximal muscle weakness, } \\
\text { hyperpigmentation }\end{array}$ & polypectomy & $\begin{array}{l}\text { recurrence of } \\
\text { tumor and CS } \\
\text { surgery }\end{array}$ & $\begin{array}{l}\text { CS symptoms } \\
\text { resolved }\end{array}$ \\
\hline $\begin{array}{l}\text { Kanno } \\
\text { et al. [22] }\end{array}$ & 39 & female & $\begin{array}{l}\text { systemic edema, general fatigue, moon face, central } \\
\text { obesity, pulmonary infection, hypertension, severe } \\
\text { hypokalemia, and metabolic alkalosis }\end{array}$ & $\begin{array}{l}\text { metyrapone, } \\
\text { dexamethasone, } \\
\text { tumor resection, local } \\
\text { irradiation }\end{array}$ & $\begin{array}{l}\text { maxillary sinus } \\
\text { resected }\end{array}$ & $\begin{array}{l}\text { CS symptoms } \\
\text { resolved }\end{array}$ \\
\hline $\begin{array}{l}\text { Josephs } \\
\text { et al. [25] }\end{array}$ & 48 & male & $\begin{array}{l}\text { leg edema, blurred vision, general weakness, } \\
\text { hypertension, hyperpigmentation, moon face, } \\
\text { hypokalemic metabolic alkalosis }\end{array}$ & $\begin{array}{c}\text { ketoconazole, surgery, } \\
\text { radiation }\end{array}$ & - & $\begin{array}{l}\text { CS symptoms } \\
\text { resolved }\end{array}$ \\
\hline \multirow[t]{2}{*}{$\begin{array}{l}\text { Koo } \\
\text { et al. [19] }\end{array}$} & 66 & female & $\begin{array}{l}\text { systemic edema, general fatigue, moon face, central } \\
\text { obesity, thin skin with purpura and hirsutism, } \\
\text { hypokalemia, metabolic alkalosis }\end{array}$ & $\begin{array}{l}\text { patient refused } \\
\text { surgery }\end{array}$ & $\begin{array}{l}\text { ketoconazole, } \\
\text { craniotomy, } \\
\text { adjuvant } \\
\text { radiotherapy }\end{array}$ & $\begin{array}{l}\text { CS symptoms } \\
\text { resolved }\end{array}$ \\
\hline & 37 & female & $\begin{array}{l}\text { moon face, central obesity, proximal muscle weakness, } \\
\text { hirsutism, hypertension, }\end{array}$ & $\begin{array}{l}\text { etoposide, ifosfamide, } \\
\text { cisplatin, radiotherapy }\end{array}$ & - & $\begin{array}{l}\text { CS symptoms } \\
\text { resolved }\end{array}$ \\
\hline $\begin{array}{l}\text { Mintzer } \\
\text { et al. [1] }\end{array}$ & 70 & male & $\begin{array}{l}\text { fatigue, confusion, severe hypertension, proximal } \\
\text { muscle weakness, hyperglycemia, hypokalemia, } \\
\text { metabolic alkalosis }\end{array}$ & $\begin{array}{l}\text { ketoconazole, surgery, } \\
\text { chemoradiotherapy }\end{array}$ & $\begin{array}{l}\text { ketoconazole } \\
\text { and octreotide }\end{array}$ & $\begin{array}{l}\text { CS symptoms } \\
\text { resolved }\end{array}$ \\
\hline $\begin{array}{l}\text { Han } \\
\text { et al. [27] }\end{array}$ & 59 & male & $\begin{array}{l}\text { nasal congestion, tearing, periorbital edema, neck } \\
\text { swelling, hypokalemia, hypertension, hyperglycemia. }\end{array}$ & $\begin{array}{l}\text { ketoconazole, } \\
\text { chemotherapy, } \\
\text { bilateral } \\
\text { adrenalectomy, } \\
\text { surgery }\end{array}$ & - & $\begin{array}{l}\text { CS symptoms } \\
\text { resolved }\end{array}$ \\
\hline \multirow[t]{2}{*}{$\begin{array}{l}\text { Hodish } \\
\text { et al. [13] }\end{array}$} & 48 & male & $\begin{array}{l}\text { leg edema, blurred vision, muscle weakness, } \\
\text { hypokalemia, metabolic alkalosis, facial swelling, } \\
\text { hyperpigmentation }\end{array}$ & \multirow[t]{2}{*}{$\begin{array}{l}\text { ketoconazole, surgery, } \\
\text { radiotherapy } \\
\text { surgery }\end{array}$} & - & $\begin{array}{l}\text { CS symptoms } \\
\text { resolved }\end{array}$ \\
\hline & 30 & female & $\begin{array}{l}\text { weight gain, moon face, skin changes, hypertension, } \\
\text { amenorrhea, hirsutism, psychological changes, } \\
\text { insomnia, buffalo hump, hyperpigmentation, acanthosis } \\
\text { nigricans, tinea versicolor }\end{array}$ & & - & $\begin{array}{l}\text { CS symptoms } \\
\text { resolved }\end{array}$ \\
\hline $\begin{array}{l}\text { Lin } \\
\text { et al. [34] }\end{array}$ & 64 & female & $\begin{array}{l}\text { general weakness, ulcerative herpes zoster patches, } \\
\text { intractable herpetic neuralgia pain, altered mental } \\
\text { testing, moon face, prominent supraclavicular fat pads, } \\
\text { truncal obesity, hypertension, pneumonia, hypokalemia }\end{array}$ & $\begin{array}{l}\text { antibiotics, } \\
\text { meropenem }\end{array}$ & - & DDD \\
\hline $\begin{array}{l}\text { Butt and } \\
\text { Olczak } \\
{[31]}\end{array}$ & 52 & male & $\begin{array}{l}\text { rhinorrhea, nasal obstruction, epistaxis, generalized } \\
\text { weakness, bilateral ankle edema, hypokalemic } \\
\text { metabolic alkalosis }\end{array}$ & surgery & metyrapone & $\begin{array}{l}\text { CS symptoms } \\
\text { resolved }\end{array}$ \\
\hline $\begin{array}{l}\text { Galioto } \\
\text { et al. [29] }\end{array}$ & 3 & male & moon face, central obesity, asthenia, hirsutism & surgery & surgery & $\begin{array}{l}\text { CS symptoms } \\
\text { resolved }\end{array}$ \\
\hline $\begin{array}{l}\text { Rodgers } \\
\text { et al. [30] }\end{array}$ & 51 & male & $\begin{array}{l}\text { hypertension, arm pain, anosmia, nasal congestion, } \\
\text { hypokalemia }\end{array}$ & surgery, radiotherapy & $\begin{array}{l}\text { tumor } \\
\text { resection, } \\
\text { spironolactone }\end{array}$ & $\begin{array}{l}\text { CS symptoms } \\
\text { resolved }\end{array}$ \\
\hline $\begin{array}{l}\text { Inagaki } \\
{[23]}\end{array}$ & 33 & male & $\begin{array}{l}\text { dysgeusia, adynamia, stomatitis, facial and extremity } \\
\text { edema, diarrhea, anxiety, irritability, insomnia, } \\
\text { psychomotor excitement }\end{array}$ & surgery & $\begin{array}{l}\text { chemotherapy, } \\
\text { metyrapone }\end{array}$ & $\begin{array}{l}\text { CS symptoms } \\
\text { reappeared }\end{array}$ \\
\hline $\begin{array}{l}\text { Mayur } \\
{[35]}\end{array}$ & 19 & male & $\begin{array}{l}\text { weight gain, pruritic skin rash, purple striae on both } \\
\text { arms and the abdomen }\end{array}$ & $\begin{array}{l}\text { chemotherapy, } \\
\text { surgery, radiotherapy }\end{array}$ & - & $\begin{array}{l}\text { CS symptoms } \\
\text { resolved }\end{array}$ \\
\hline
\end{tabular}

CS - Cushing's syndrome; DDD - death due to disease; NI - no information 
22]. Anatomical location of the ACTH-secreting neuroblastoma may cause misleading IPSS results. Therefore, Kanno et al. recommend selective sampling from the cavernous sinus rather than the inferior petrosal sinus to avoid confusion [22]. Moreover, in the other case, both HDDST and $\mathrm{CRH}$ stimulation tests had suggested pituitary ACTH-dependent CS, until IPSS revealed EAS [13]. Suppression of POMC gene transcription in the tumor cells requires higher doses of glucocorticoids than in the pituitary, but in some cases the mechanism may work normally. That is why, in some patients with the EAS, cortisol levels are suppressed after $8 \mathrm{mg}$ dexamethasone, as it occurs in pituitary CD [17]. On the other hand, Inagaki suggested that in one case of EAS secondary to ONB there was positive feedback regulation between cortisol and $\mathrm{ACTH}$ in the tumor. In this case, Decadron (dexamethasone), used with chemotherapy, may have triggered ACTH secretion by means of positive feedback regulation [23]. Immediate normalization in cortisol and ACTH levels as a response to metyrapone, which can inhibit production of cortisol but not ACTH directly, supports this hypothesis. It follows that the results of diagnostic procedures performed during EAS secondary to ONB could be very confusing and unclear.

Somatostatin receptor scintigraphy could be useful in diagnosing ACTH-secreting tumors. Octreotide is a somatostatin analogue that binds to the somatostatin receptors. The octreotide radionuclide scans are sensitive in identification of somatostatin receptor-expressing tumors, which constitute up to $80 \%$ of ectopic ACTH-secreting tumors, but they are not helpful when these receptors are absent. The therapeutic response to octreotide cannot be predicted by the results of an octreotide scan [24]. Diagnostic use of octreotide was reported in five cases of ACTH-secreting ONB which revealed tracer uptake corresponding to the ONB in all of them [1,13, 23-26]. Octreotide with ketoconazole was also used therapeutically to suppress hypercortisolemia in three ONBs associated with EAS with different results: in all cases serum ACTH concentration was reduced, but it remained elevated [1, 19, 27].

In 16 of the reported ACTH-secreting ONBs, performed tests on the biopsy samples or excised tumors included ACTH immunohistochemical staining. Histologically there was no reported difference between $\mathrm{ACTH}$-secreting and ACTH-nonsecreting ONB. In 14 cases the results of ACTH immunohistochemical staining were positive. Only in two cases did the clinical features of EAS occur despite negative staining for ACTH $[19,28]$. In the first case, the symptoms disappeared when the tumor was resected, but in the second the patient died.

One pediatric case of CS secondary to ONB was reported by Galioto in a 3-year-old boy. He underwent endoscopic surgery of ONB at the age of 10 months and had already had elevated cortisolemia and moon face; however, there was no diagnosis of CS. At the age of 28 months, CS symptoms appeared with high levels of serum ACTH and cortisol in the laboratory findings. MRI revealed a right lymph nodal mass. After a right parapharyngeal lymphadenectomy the symptoms of CS disappeared [29]. Cushing's syndrome associated with ONB relapse has been described several times in adults. Arnesen reported recurrence of both ONB and CS, which occurred 5 years after initial treatment, whereas first signs of EAS connected with ONB relapse have been reported four times [1, 23, 30, 31].

The majority of reported ACTH-secreting ONB had a favorable outcome, probably because the clinical manifestations of CS led to an earlier diagnosis and treatment. Only two patients died. It is possible that the ability to synthesize and secrete ACTH required a more differentiated and less aggressive tumor [13]. However, in other tumors development of CS may be an adverse prognostic factor, as in SCLC [32]. An unfavorable outcome in patients with SCLC and ectopic ACTH secretion results mainly from associated bacterial or opportunistic infections [33]. Severe infections during the course of EAS in ONBS occurred in 5 patients. Interestingly, Han et al. carried out bilateral adrenalectomy in a patient with recurrent infections of the colostomy site and other life-threatening complications due to EAS secondary to ONB, and his condition significantly improved [27].

\section{Syndrome of inappropriate ADH secretion}

Syndrome of inappropriate ADH secretion is a condition in which excessive release or action of ADH results in persistent hyponatremia and inappropriately elevated urine osmolality. Syndrome of inappropriate ADH secretion is the most common cause of hyponatremia and is responsible for one third of all cases [38]. There are various mechanisms leading to SIADH. It usually results from increased secretion of ADH by the pituitary gland or ectopic secretion from another source. Other mechanisms include increased sensitivity to $\mathrm{ADH}$ in the kidney, exogenous administration of ADH or desmopressin, cachexia, AIDS, and many more [39]. Differential diagnosis includes conditions in which euvolemic hyponatremia occurs such as hypothyroidism and glucocorticoid deficiency [40]. Hyponatremia may also result from cerebral salt wasting (CSW). In CSW the patient is truly volume contracted and has inappropriate natriuresis. It is important to distinguish between CSW and SIADH, because of different treatment algorithms. There is one case of CSW in a patient with a history of ONB. An $\mathrm{MRI}$ of the patient's brain revealed two basal frontal lobe lesions; nevertheless, biopsy revealed only necrotic tissue without any evidence of malignancy [41].

The symptoms of SIADH are mostly neurological and depend on both the degree of hyponatremia and the rate at which hyponatremia develops. When hyponatremia develops slowly, patients may be asymptomatic or have nonspecific symptoms such as anorexia, nausea, vomiting, irritability, headaches, and abdominal cramps. On the other hand, when hyponatremia occurs rapidly, patients tend to have more severe symptoms. When the serum sodium level is below $120 \mathrm{mEq}$ or serum osmolality is less than $240 \mathrm{mOsm} / \mathrm{kg}$, patients can experience cerebral edema, regardless of the rate of decrease. It may manifest as headache, nausea, restlessness, irritability, muscle cramps, generalized weakness, depressed reflexes, confusion, coma, or seizures. Serious neurological complications such as permanent brain damage, brainstem herniation, or respiratory arrest may occur [39]. 
In cancer patients, ectopic secretion of ADH by tumor cells causes paraneoplastic SIADH. This condition has been associated with SCLC, bronchogenic carcinoma, duodenal tumors, pancreatic tumors, thymus tumors, sarcoma, malignant histiocytosis, mesothelioma, and other occult tumors [39]. Syndrome of inappropriate ADH secretion has been reported in 1.5 to 3\% of patients with head and neck cancer [42]. It may accompany squamous carcinomas, ONBs, small cell neuroendocrine carcinomas, adenoid cystic carcinomas, and undifferentiated carcinomas and sarcoma. Malignancies of the head and neck related to SIADH have most often been located in the oral cavity, and less often in the larynx, nasopharynx, hypopharynx, nasal cavity, maxillary sinus, parapharyngeal space, salivary glands, and oropharynx [43].

Since the first description in 1967 [44], there have been 35 cases of SIADH due to ONB to our knowledge (Table 2). The mean age of patients was 41.5. Among described patients were 22 females and 11 males. In 15 cases ADH secretion by the tumor was proven by assay of tumor tissue, whereas in 1 case immunostaining for ADH was negative [45]. There was no information about evidence of $\mathrm{ADH}$ secretion by the tumor in the other cases. Three SIADH-associated ONBs were primary sellar neuroblastomas. Interestingly, they represent approximately $27 \%$ of all primary sellar neuroblastomas reported in the literature. These ONBs are thought to originate from the ganglion of Locy that grows between the olfactory fossa and the telencephalic vesicle [46]. There is also a distinctive case of $\mathrm{SIADH}$ in a patient with sinonasal teratocarcinosarcoma, which was composed of ONB areas (90\% of tumor) and mature craniopharyngioma (10\% of tumor). Immunostaining for ADH was positive only in the ONB cells [47]. Besides paraneoplastic, there is also one case of SIADH in advanced ONB induced by cisplatin (CDDP) [48]. A similar situation was also reported in some other cancer patients after CDDP administration [49].

Among all cases, in 26 (75\%) after treatment SIADH resolution was recorded, 4 (11.5\%) patients died, in 2 (5\%) SIADH persisted, and in 1 reset of osmostat (left-shift set point of osmolality) occurred.

Senchak et al. described a female patient with ectopic ONB which arose from the middle nasal cavity [50]. She had a 3-year history of hyponatremia prior to ONB diagnosis, which was diagnosed as SIADH and treated by demeclocycline. Furthermore, she became pregnant shortly after ONB discovery. Sodium level and plasma osmolality decreased normally in early pregnancy due to the altered threshold for ADH release and for thirst [51], so there was a risk of overlap between this mechanism and SIADH. To avoid the risk of severe hyponatremia, endoscopic total resection of the neoplasm was performed. After surgery her sodium level and osmolality normalized. She also had an uncomplicated delivery of her pregnancy. Interestingly, in another case reported by Renneboog, hyponatremia associated with ONB normalized during pregnancy and reoccurred after delivery [52]. A possible explanation may be the action of placental peptidases, which are capable of inactivating $\mathrm{ADH}$ [53].
Olfactory neuroblastoma is a malignancy with a long natural history due to slow progression. Nevertheless, local recurrences occur in 30\% of patients, cervical node metastases in $23 \%$, and distant metastases in $8 \%$ of cases. Recurrence or progression even $>10$ years after initial presentation are reported [8]. In one case, incidental diagnosis of hyponatremia due to SIADH with a lack of other symptoms led to the finding of ONB recurrence 16 years after primary tumor resection [54]. Interestingly, SIADH did not accompany the primary tumor. On the other hand, Myers et al. reported an ADH-secreting primary ONB, which relapsed in the lymph node, but without SIADH reappearance, which can imply that recurrent tumor cells probably lost the ability of ADH production [55].

Another interesting case of SIADH secondary to ONB was presented by Muller et al. [56]. A 47-year-old man was admitted to a psychiatric hospital because of a first major depressive episode. He also had a history of hyponatremia due to SIADH of unknown origin. Major depression may be associated with numerous endocrine disturbances such as CS, Addison's disease, hyperthyroidism, hypothyroidism, hyperprolactinemia and also SIADH [57]. ADH when over-expressed and over-released may contribute to hyper-anxiety and depression-like behaviors, because ADH belongs to the neuropeptide system critically involved in higher brain functions [58]. After admission the patient underwent a combined dexamethasone-CRH stimulation test and neither corticotropin nor cortisol plasma levels have increased. Heuser et al. showed that psychiatric patients, regardless of diagnostic classification, release more cortisol and ACTH after this test in comparison with controls [59]. This hyperactivity results from increased central production of $\mathrm{CRH}$ and desensitization of the glucocorticoid receptor binding system in the hippocampus, which is involved in feedback inhibition of hypothalamic-pituitary-adrenocortical axis activity [60]. Corticotropin-releasing hormone and $\mathrm{ADH}$ are known for being the most important stimulants of ACTH secretion. Several studies have shown that the ACTH response to both $\mathrm{CRH}$ and $\mathrm{ADH}$ undergoes desensitization [61], especially when there is a chronically elevated level of $\mathrm{CRH} / \mathrm{ADH}$ as in this case of SIADH. Psychiatric symptoms such as major depression, anxiety, hypomania, psychosis and mania may be part of CS clinical manifestations [62]. Inagaki presented a case of ONB relapse manifesting with anxiety, irritability, insomnia, psychomotor excitement and then depressed mood and suicidal ideation. The further investigation revealed CS and treatment with metyrapone was started. The patient's cortisol levels and ACTH levels immediately became normal and psychiatric manifestations resolved. Depression, decreased libido, increased irritability, mood swings, insomnia, and short attention span were also noted in Hodish's patient with EAS associated with ONB [13]. Moreover, besides PNS, in ONB depression and other psychiatric symptoms may also be signs of frontal lobe dysfunction $[63,64]$.

Recurrent hyponatremia after an ADH-secreting tumor resection have been proposed as a potential marker for persistent disease or tumor recurrence. Nevertheless, Perry et al. reported reset osmostat after resection of ADH-secreting ONB, which led to recurrent hyponatremia. Reset 
Table 2. Case reports of olfactory neuroblastoma associated with syndrome of inappropriate ADH secretion (SIADH)

\begin{tabular}{|c|c|c|c|c|c|}
\hline Study & Age & Sex & Treatment & $\begin{array}{l}\text { Treatment at } \\
\text { recurrence }\end{array}$ & SIADH post Tx/Outcome \\
\hline Bouche et al. [44] & 34 & male & surgery & - & resolved \\
\hline Pope et al. [80] & 56 & female & surgery + radiotherapy & - & resolved \\
\hline Singh et al. [86] & 17 & female & cobalt therapy & - & DDD \\
\hline Srigley et al. [87] & 33 & female & $\begin{array}{l}\text { surgery + radiotherapy and } \\
\text { chemotherapy }\end{array}$ & - & resolved \\
\hline Cullen et al. [88] & 26 & female & surgery + radiotherapy & - & resolved \\
\hline Osterman et al. [89] & 28 & male & surgery + radiotherapy & - & resolved \\
\hline Myers et al. [55] & 79 & female & conservative treatment & - & DDD \\
\hline Al Ahwal et al. [45] & 27 & male & surgery & radiotherapy & resolved \\
\hline $\begin{array}{l}\text { Boursier [69] } \\
\text { Bernard [68] }\end{array}$ & 22 & male & surgery & - & resolved \\
\hline Muller et al. [56] & 47 & male & surgery & - & $\begin{array}{c}\text { resolved } \\
\text { normalization of psychiatric symptoms }\end{array}$ \\
\hline Kleinschmidt et al. [47] & 59 & male & surgery & surgery & DDD \\
\hline Miura et al. [70] & 56 & male & $\begin{array}{l}\text { surgery + radiotherapy and } \\
\text { chemotherapy }\end{array}$ & & $\begin{array}{c}\text { maturation to ganglioneuroma after } \\
\text { chemotherapy } \\
\text { DDD }\end{array}$ \\
\hline \multirow[t]{2}{*}{ Freeman et al. [71] } & 51 & female & surgery & - & resolved \\
\hline & 42 & female & surgery & - & resolved \\
\hline Plasencia et al. [54] & 34 & female & surgery + radiotherapy & $\begin{array}{c}\text { surgery + } \\
\text { radiotherapy }\end{array}$ & resolved \\
\hline Maeda et al. [72] & 61 & male & radiotherapy & radiotherapy & resolved \\
\hline Perry et al. [73] & 56 & female & surgery & - & reset osmostat \\
\hline Senchak et al. [50] & 28 & female & surgery & - & resolved \\
\hline \multirow[t]{3}{*}{ Gray et al. [66] } & 29 & male & $\begin{array}{l}\text { surgery + chemotherapy }+ \\
\text { radiotherapy }\end{array}$ & - & resolved \\
\hline & 25 & female & surgery + radiotherapy & - & resolved \\
\hline & 32 & female & surgery + radiotherapy & - & resolved \\
\hline Iliades et al. [74] & 57 & female & surgery + radiotherapy & - & resolved \\
\hline Verbalis et al. [75] & 40 & female & surgery & - & resolved \\
\hline Yang et al. [76] & 25 & female & chemotherapy + radiotherapy & - & resolved \\
\hline Cho et al. [77] & 62 & male & chemotherapy & - & resolved \\
\hline Nabili et al. [78] & $\mathrm{NI}$ & female & surgery & $\mathrm{NI}$ & resolved; BP normalization \\
\hline Dupuy et al. [79] & 44 & female & surgery & - & PRL normalization, SIADH \\
\hline Schmalisch et al. [46] & 43 & female & surgery + radiotherapy & - & PRL normalization, SIADH \\
\hline Radotra et al. [81] & 29 & male & surgery + radiotherapy & - & resolved \\
\hline Hoorn et al. [82] & 29 & female & endonasal ethmoidectomy & - & resolved \\
\hline Wade et al. [83] & 59 & female & surgery & chemotherapy & resolved \\
\hline Renneboog [52] & 28 & female & surgery + radiotherapy & - & resolved \\
\hline Garcia Vincente [84] & $\mathrm{NI}$ & $\mathrm{NI}$ & $\mathrm{NI}$ & - & $\mathrm{NI}$ \\
\hline Le Guillou et al. [85] & 60 & female & surgery & - & resolved \\
\hline Gabbay et al. [67] & 50 & male & surgery & - & resolved \\
\hline
\end{tabular}

$D D D$ - death due to disease; NI-no information; Tx-treatment

osmostat is an altered pattern of $\mathrm{ADH}$ secretion in which the threshold for ADH secretion is moved downward. Hyponatremia in these patients will be limited to a value close to the new osmotic set point [38]. A water load test was used in this case to differentiate reset osmostat from unregulated $\mathrm{ADH}$ secretion, which may occur with tumor relapse. With this procedure, a fasting is given specific quantities of water, then the amount ofurine produced and the changes in urine and blood osmolality and ADH level are monitored over time [65]. 
Plasencia et al. pointed out that most cases of SIADH from other etiologies are relatively mild, and hyponatremia is generally of little clinical significance, while severe hyponatremia has been described in relation to ONB [54]. Many cases of ONB inducing subclinical SIADH probably have passed unnoticed, and the general number of ADH-secreting ONB may be significantly underestimated. In one retrospective analysis of 21 patients, the prevalence of SIADH was $14 \%$ [66]. In 18 cases hyponatremia occurred parallel to ONB diagnosis, whereas in $17 \mathrm{SIADH}$ preceded ONB. In some cases Gabbay et al. emphasized that the time interval between the onset of SIADH and the diagnosis of ONB is exceptionally long in this neoplasm [67]. This reflects low awareness of physicians in this area.

\section{Catecholamine secretion}

Symptomatic catecholamine secretion by tumors is a rarity. The majority of these tumors are pheochromocytomas and paragangliomas. Pheochromocytomas and sympathetic paragangliomas usually release norepinephrine and/or epinephrine, while $23 \%$ of parasympathetic paraganglia-derived tumors secrete only dopamine [90]. As far as head and neck tumors are concerned, approximately $20 \%$ of head and neck paragangliomas also produce significant amounts of catecholamines [91]. Main signs and symptoms include paroxysmal or sustained hypertension, severe headaches, palpitations and sweating resulting from hormone excess. Less common are fatigue, nausea, weight loss, constipation, flushing, and fever [92].

Neuroblastomas, pediatric tumors of the sympathetic nervous system, are also associated with catecholamine secretion. Expression of tyrosine hydroxylase could be used diagnostically for the detection of residual NB cells. Conversely, ONBs do not usually secrete catecholamines, and tyrosine hydroxylase is not generally expressed in these tumors [93]. Nevertheless, there are 5 cases of catecholamine-secreting ONBs to our knowledge. Three of them were clinically inactive and catecholamine production was revealed by immunohistochemical and molecular analysis [94-96].

Nabili et al. reported a unique case of tumor which secreted both $\mathrm{ADH}$ and catecholamines. Patient symptoms included hypernatremia and hypertension. Laboratory studies showed increased blood levels of ADH and normetanephrine and elevated urine metanephrine. Mild 123I-metaiodobenzylguanidine (123I-MIBG) uptake in the right nasal region suggested a catecholamine-secreting tumor. Perioperative treatment with $\alpha$-blockers, phenoxybenzamine, and phentolamine was applied to prevent intraoperative hypertension. After surgery there were no signs of SIADH, and urine catecholamine levels were markedly decreased. The progressive decrease in catecholamine levels after treatment suggests that catecholamine levels may serve as useful markers for residual disease or recurrence.

Intraoperative unpredictable paroxysmal release of catecholamines can result in catastrophic cardiovascular complications in a previously undiagnosed patient [97]. An intraoperative hypertensive crisis during the first of two planned stages of ONB surgery in a 56-year-old man was reported by Salmasi et al. [98]. Further investigation revealed increased levels of blood and urinary catecholamines. After the second stage of surgery, immunohistochemical studies of tumor tissue revealed that tumor cells were positive for tyrosine hydroxylase. Catecholamine production should be considered in the case of unexpected extreme hypertension during surgical resection of ONB.

\section{Hypercalcemia}

Hypercalcemia affects up to 10 to $30 \%$ of cancer patients, most frequently those with breast and lung cancer and myeloma [99]. Hypercalcemia is a common complication in many advanced cancers and has a poor prognosis due to the fact that usually it is associated with disseminated disease. Different humoral factors that are released by tumor cells, either locally or systematically, can affect calcium level regulatory systems. The main humoral factor associated with cancer-related hypercalcemia is PTHrP, which is produced by many solid tumors. PTHrP secretion by tumor accounts for $80 \%$ of HHM cases [100]. Less common humoral factors secreted by tumors are vitamin D and PTH. Osteolytic activity at sites of skeletal metastases account for $20 \%$ of cases [11].

Sharma et al. presented the only known case of hypercalcemia as a complication of ONB. The patient was a 52-year-old male smoker with ONB at Kadish stage C, who despite metastatic disease had maintained a good performance status and quality of life. He was treated with chemotherapy and radiotherapy. Surgery of the tumor was not performed because the patient declined. Six months after the last course of radiotherapy, symptomatic hypercalcemia occurred (corrected serum calcium $12.7 \mathrm{mg} / \mathrm{dl}$; normal 9-10.3 mg/dl). Treatment included forced saline diuresis, subcutaneous calcitonin, and intravenous gallium nitrate. Despite a backache perceived by the patient, there were no spinal metastases in the administered MRI. Hypercalcemia had recurred for several months and proper treatment was performed. At the time of the next admission, the serum PTH was 5 pg/ml (normal 10-60 pg/dl) despite severe symptomatic hypercalcemia that did not respond to aggressive treatment, which was the cause of death.

Hypercalcemia, which is resistant to treatment can be induced by ectopic PTH secretion or primary hyperparathyroidism, but low levels of PTH in this case excluded that. Negative whole spine MRI makes widespread bone metastases unlikely. Even though Sharma et al. did not measure the level of PTHrP, the HHM secondary to PTHrP secretion by the primary tumor or by metastases is a likely cause of hypercalcemia in this case. HHM may be an important adverse prognostic indicator, as in other malignancies, having serious implications for diagnosis, prognosis, and treatment decisions in ONB.

\section{Hyperprolactinemia}

Hyperprolactinemia in cancer patients is often associated with ectopic prolactin (PRL) production by tumors. Primary sellar neuroblastomas are the only known forms of ONBs in which hyperprolactinemia were reported. How- 
Table 3. Case reports of neurological paraneoplastic syndromes in olfactory neuroblastoma

\begin{tabular}{|c|c|c|c|c|c|c|c|}
\hline Study & Sex & Age & $\begin{array}{l}\text { Clinical manifestation/ } \\
\text { course }\end{array}$ & Onconeural antibodies & Neuroimaging & Treatment & Outcome \\
\hline $\begin{array}{l}\text { Van } \\
\text { Dienst } \\
\text { et al. } \\
{[106]}\end{array}$ & female & 51 & $\begin{array}{l}\text { at admission: opsoclonus, } \\
\text { vertigo, vomiting, severe } \\
\text { ataxia of the four limbs, } \\
\text { dysarthria, sporadic } \\
\text { myoclonic muscle jerks; } \\
\text { two postoperative relapses }\end{array}$ & $\begin{array}{l}\text { anti-Hu, anti-Yo and anti-Ri } \\
\text { - negative }\end{array}$ & $\begin{array}{l}\text { a tumor of } \\
\text { the nasal } \\
\text { septum and } \\
\text { the ethmoidal } \\
\text { sinuses }\end{array}$ & $\begin{array}{l}\text { methylprednisolone; } \\
\text { surgery; } \\
\text { chemotherapy and } \\
\text { radiotherapy }\end{array}$ & $\begin{array}{l}\text { patient able } \\
\text { to walk } \\
\text { about with } \\
\text { a walking } \\
\text { aid }\end{array}$ \\
\hline $\begin{array}{l}\text { Maeda } \\
\text { et al. } \\
{[109]}\end{array}$ & male & 65 & $\begin{array}{l}7 \text { years before admission } \\
\text { olfactory neuroepithelioma; } \\
\text { at admission: } \\
\text { gait instability; dysmetria } \\
\text { marked in both legs } \\
\text { and poor heel-shin test; } \\
\text { downbeat nystagmus; } \\
\text { tandem gait was impossible }\end{array}$ & $\begin{array}{l}\text { anti-Hu - positive; } \\
\text { anti-Yo, Ri, CV2, Tr, Ma, } \\
\text { amphiphysin, glutamic acid } \\
\text { decarboxylase - negative. } \\
\text { Immunohistochemistry } \\
\text { with anti-HuD antibody - } \\
\text { part of the tumor expressed } \\
\text { Hu protein }\end{array}$ & $\begin{array}{l}\text { bilateral } \\
\text { leukoaraiosis } \\
\text { at bilateral } \\
\text { frontal lobes; } \\
\text { slightly atrophic } \\
\text { cerebellum }\end{array}$ & $\mathrm{NI}$ & $\begin{array}{l}4 \text { years after } \\
\text { discharge, } \\
\text { the } \\
\text { cerebellar } \\
\text { ataxia did } \\
\text { not worsen } \\
\text { further }\end{array}$ \\
\hline
\end{tabular}

$\mathrm{NI}-$ no information

ever, it is thought to be a consequence of the stalk effect, not ectopic PRL production [46, 79, 101]. Nevertheless, Skinner presented an interesting alternative hypothesis in which he stated that suprasellar tumors secrete a specific pars tuberalis factor, like preprotachykinin A derived tachykinins, substance $P$ and/or neurokinin $A$, that stimulates PRL secretion [102]. Therefore, hyperprolactinemia in these tumors would have features of PNS.

\section{Neurological paraneoplastic syndromes}

Opsoclonus-myoclonus-ataxia (OMA) is a rare autoimmune condition characterized by disinhibition of the fastigial nucleus of the cerebellum. Symptoms includes involuntary multidirectional saccades with horizontal, vertical, and torsional components and brief multifocal myoclonic muscle jerks usually accompanied by cerebellar dysfunction with dysarthria and ataxia, hence the name "dancing eyes, dancing feet syndrome" [103]. Neuronal damage is probably caused by T-cell dependent reactions. Nevertheless, OMA and some other neurological PNS are known to be associated with presence of special antibodies, known as onconeural antibodies (anti-Hu, Yo, Ri, CRMP5, Ma, amphiphysin), which are directed against intracellular antigens expressed by the tumor. Although they have low pathogenic significance, they are useful diagnostic markers of paraneoplastic etiology [104]. However, the lack of detectable onconeural antibodies does not exclude the PNS diagnosis. Half of all cases occur in children with neuroblastoma, frequently showing diffuse and extensive lymphocytic infiltration with lymphoid follicles [105]. In adults there are multiple etiologies: besides paraneoplastic (most frequently due to SCLC and breast cancer), also post-infectious, celiac disease, pregnancy, post-vaccination and idiopathic [106]. There is one reported case of OMA due to ONB. In contrast to endocrine PNS, paraneoplastic neurologic syndromes are detected before cancer is diagnosed in $80 \%$ of cases, and this was the case in the single reported ONB patient [11].

In this case, a 51-year-old woman presented subacute onset of OMA. Clinical findings are presented in Table 2. Two weeks prior to admission, the patient underwent a bi- opsy of a polypoid lesion in the right nasal cavity. Pathology revealed a Hyams' grade 4 ONB with diffuse and extensive lymphocytic infiltration, but without lymphoid follicles.

Conversely to the monophasic course observed in idiopathic OMA, the relapsing-remitting profile is typical for paraneoplastic OMA, as seen in this case [107].

Pediatric neuroblastoma patients with OMA show a less aggressive course of the disease. These tumors also have a tendency to involute spontaneously or mature, and in $90 \%$ no metastases are found [105]. Due to these facts, neuroblastic tumors in patients with OMA are associated with a good prognosis. However, in adults the majority of patients with paraneoplastic OMA make only a partial recovery, and some even die due to severe encephalopathy and coma development [107]. In the presented ONB patient with OMA, skin metastases were found, but after proper treatment her state improved and no other lesions were reported.

Olfactory neuroepithelioma is classified as a variant of ONB [108]. Maeda et al. reported a case of a 65-year-old man with recurrence of olfactory neuroepithelioma in the parotid gland, with parallel onset of neurological manifestation (Table 3) [109]. The recurrence might have enhanced the immune response. Despite resection of the recurrent tumor, the cerebellar ataxia worsened for several months after surgery. However, it did not progress thereafter.

In patients with neurological symptoms and Hu antibody, olfactory neuroepithelioma should be considered when a neoplasm is not found at common sites such as the lung or breast.

\section{Conclusions}

Amongst all PNS that may occur in ONB, SIADH was the most frequently reported. Physicians should be aware that idiopathic hyponatremia may be caused by ONB. Similarly, in long lasting CS without an obvious cause, one should consider "looking at the sinus". However, caution is strongly recommended when analyzing IPSS, HDDST and $\mathrm{CRH}$ stimulation test findings due to the high prevalence of false results. Both SIADH and EAS are generally associated with good prognosis. 
Other PNS, especially neurological, are extremely rare in these tumors. Opsoclonus-myoclonus-ataxia is a relatively common PNS in pediatric neuroblastoma and in one case was associated with ONB. This suggests that occasionally ONB may behave like a pediatric neuroblastoma.

\section{The authors declare no conflict of interest.}

\section{References}

1. Mintzer DM, Zheng S, Nagamine M, Newman J, Benito M. Esthesioneuroblastoma (Olfactory Neuroblastoma) with Ectopic ACTH Syndrome: a multidisciplinary case presentation from the Joan Karnell cancer center of Pennsylvania Hospital. Oncologist 2010; 15: 51-8.

2. Ogura JH, Schenck NL. Unusual nasal tumors. Problems in diag nosis and treatment. Otolaryngol Clin North Am 1973; 6: 813-37.

3. Cohen ZR, Marmor E, Fuller GN, DeMonte F. Misdiagnosis of olfactory neuroblastoma. Neurosurg Focus 2002; 12: e3.

4. Thompson LD. Olfactory neuroblastoma. Head Neck Pathol 2009; 3: 252-9.

5. Kadish S, Goodman M, Wang CC. Olfactory neuroblastoma. A clinical analysis of 17 cases. Cancer 1976; 37: 1571-6.

6. Morita A, Ebersold MJ, Olsen KD, Foote RL, Lewis JE, Quast LM. Esthesioneuroblastoma: prognosis and management. Neurosurgery 1993; 32: 706-14; discussion 714-5.

7. Ow TJ, Bell D, Kupferman ME, Demonte F, Hanna EY. Esthesioneuroblastoma. Neurosurg Clin N Am 2013; 24: 51-65.

8. Mattavelli F, Pizzi N, Pennacchioli E, Radaelli S, Calarco G, Quattrone P, Patelli L, Spinelli P. Esthesioneuroblastoma metastatic to the trachea. Acta Otorhinolaryngol Ital 2009; 29: 164-8.

9. Kasprzak A, Zabel M, Biczysko W. Selected markers (chromogranin $A$, neuron-specific enolase, synaptophysin, protein gene product 9.5) in diagnosis and prognosis of neuroendocrine pulmonary tumours. Pol J Pathol 2007; 58: 23-33.

10. Oberg K, Janson ET, Eriksson B. Tumour markers in neuroendocrine tumours. Ital J Gastroenterol Hepatol 1999; 31: S160-2.

11. Pelosof LC, Gerber DE. Paraneoplastic syndromes: an approach to diagnosis and treatment. Mayo Clin Proc 2010; 85: 838-54.

12. Ejaz S, Vassilopoulou-Sellin R, Busaidy NL, et al. Cushing syndrome secondary to ectopic adrenocorticotropic hormone secretion: the University of Texas MD Anderson Cancer Center Experience. Cancer 2011; 117: 4381-9.

13. Hodish I, Giordano TJ, Starkman MN, Schteingart DE. Location of ectopic adrenocortical hormone-secreting tumors causing Cushing's syndrome in the paranasal sinuses. Head Neck 2009; 31: 699-706.

14. Suzuki J, Otsuka F, Ogura T, et al. An aberrant ACTH-producing ectopic pituitary adenoma in the sphenoid sinus. Endocr J 2004; 51: 97-103.

15. Thomas T, Zender S, Terkamp C, Jaeckel E, Manns MP. Hypercortisolaemia due to ectopic adrenocorticotropic hormone secretion by a nasal paraganglioma: a case report and review of the literature. BMC Res Notes 2013; 6: 331.

16. Granato L, Prospero JD, Martini Filho D. Nasal paraganglioma: A case report and literature review. Int Arch Otorhinolaryngol 2013; 17: $92-5$.

17. Terzolo M, Reimondo G, Alì A, Bovio S, Daffara F, Paccotti P, Angeli A. Ectopic ACTH syndrome: molecular bases and clinical heterogeneity. Ann Oncol 2001; 12: S83-7.

18. Newell-Price J, Trainer P, Besser M, Grossman A. The diagnosis and differential diagnosis of Cushing's syndrome and pseudo-Cushing's states. Endocr Rev 1998; 19: 647-72.

19. Koo BK, An JH, Jeon KH, et al. Two cases of ectopic adrenocorticotropic hormone syndrome with olfactory neuroblastoma and literature review. Endocr J 2008; 55: 469-75.

20. Swearingen B, Katznelson L, Miller K, Grinspoon S, Waltman A, Dorer DJ, Klibanski A, Biller BM. Diagnostic errors after inferior petrosal sinus sampling. J Clin Endocrinol Metab 2004; 89: 3752-63.
21. Wiggam MI, Heaney AP, Mcllrath EM, McCance DR, Sheridan B, Hadden DR, Atkinson AB. Bilateral inferior petrosal sinus sampling in the differential diagnosis of adrenocorticotropin-dependent Cushing's syndrome: a comparison with other diagnostic tests. J Clin Endocrinol Metab 2000; 85: 1525-32.

22. Kanno K, Morokuma Y, Tateno T, Hirono Y, Taki K, Osamura RY, Hirata Y. Olfactory neuroblastoma causing ectopic ACTH syndrome. Endocr J 2005; 52: 675-81.

23. Inagaki M. Metyrapone for Cushing's Syndrome. Am J Psychiatry 2002; 159: 1246-6.

24. Uwaifo GI, Koch CA, Hirshberg B, Chen CC, Hartzband P, Nieman LK, Pacak K. Is there a therapeutic role for octreotide in patients with ectopic Cushing's syndrome? J Endocrinol Invest 2003; 26: 710-7.

25. Josephs L, Jones L, Marenette L, McKeever P. Cushing's syndrome: an unusual presentation of olfactory neuroblastoma. Skull Base 2008; 18: 73-6.

26. Yu J, Koch CA, Patsalides A, Chang R, Altemus RM, Nieman LK, Pacak K. Ectopic Cushing's syndrome caused by an esthesioneuroblastoma. Endocr Pract 2004; 10: 119-24.

27. Han JY, Mirsadraei L, Yeh MW, Suh JD, Yong WH, Bergsneider M, Heaney AP. Bilateral adrenalectomy: lifesaving procedure in severe Cushing syndrome. Endocr Pract 2012; 18: e85-90.

28. Reznik M, Melon J, Lambricht M, Kaschten B, Beckers A. Neuroendocrine tumor of the nasal cavity (esthesioneuroblastoma). Apropos of a case with paraneoplastic Cushing's syndrome. Ann Pathol 1987; 7: 137-42.

29. Galioto S, Di Petrillo A, Pastori M, Arecchi A. Metastatic esthesioneuroblastoma secreting adrenocorticotropic hormone in pediatric patients. J Craniofac Surg 2011; 22: 1924-9.

30. Rodgers S, Moshel Y, Mikolaenko I, Gilbert A, Babu R. Recurrent Esthesioneuroblastoma Presenting as an ACTH Paraneoplastic Syndrome. Int I Neurosurg 2012; 8.

31. Butt MI, Olczak S. Cushing's syndrome secondary to recurrent olfactory neuroblastoma. Endocr Abstr 2006; 12: P116.

32. Dimopoulos MA, Fernandez JF, Samaan NA, Holoye PY, Vassilopoulou-Sellin R. Paraneoplastic Cushing's syndrome as an adverse prognostic factor in patients who die early with small cell lung cancer. Cancer 1992; 69: 66-71.

33. Collichio FA, Woolf PD, Brower M. Management of patients with small cell carcinoma and the syndrome of ectopic corticotropin secretion. Cancer 1994; 73: 1361-7.

34. Lin H-H, Lin C-M, Tseng H-K. Refractory post-herpetic neuralgia as an initial presentation of olfactory neuroblastoma-related ectopic ACTH syndrome. Int J Gerontol 2009; 3: 81-4.

35. Mayur N, Bordoni RE, Locandro D, McLaughlin M. Cushing's syndrome due to ectopic adrenocorticotrophic hormone production by olfactory neuroblastoma. Endocr Pract 2014; 20: e47-52.

36. Fish S, Harish S, Tapino E, et al. Ectopic ACTH syndrome caused by olfactory neuroblastoma. Resident Staff Physician 2005; 51: 30-5.

37. Arnesen MA, Scheithauer BW, Freeman S. Cushing's syndrome secondary to olfactory neuroblastoma. Ultrastruct Pathol 1994; 18: 61-8.

38. Gross P. Clinical management of SIADH. Ther Adv Endocrinol Metab 2012; 3: 61-73.

39. Balasubramanian A, Flareau B, Sourbeer JJ. Syndrome of inappropriate antidiuretic hormone secretion. Hosp Physician 2007; 4: 33-7

40. Castillo JJ, Vincent M, Justice E. Diagnosis and management of hyponatremia in cancer patients. Oncologist 2012; 17: 756-65.

41. Gutierrez OM, Lin HY. Refractory hyponatremia. Kidney Int 2007 ; 71: 79-82.

42. Zohar Y, Talmi YP, Finkelstein Y, Nobel M, Gafter U. Syndrome of inappropriate antidiuretic hormone secretion in cancer of the head and neck. Ann Otol Rhinol Laryngol 1991; 100: 341-4.

43. Ferlito A, Rinaldo A, Devaney KO. Syndrome of inappropriate antid iuretic hormone secretion associated with head neck cancers: review of the literature. Ann Otol Rhinol Laryngol 1997; 106: 878-83.

44. Bouche J, Guiot G, Tessier P, Frèche C, Narcy P. A further case of tumor of the olfactory placode. Sem Hop 1967; 43: 587-91.

45. al Ahwal M, Jha N, Nabholtz JM, Hugh J, Birchall I, Nguyen GK. Olfactory neuroblastoma: report of a case associated with inappropriate antidiuretic hormone secretion. J Otolaryngol 1994; 23: 437-9. 
46. Schmalisch K, Psaras T, Beschorner R, Honegger J. Sellar neuroblastoma mimicking a pituitary tumour: case report and review of the literature. Clin Neurol Neurosurg 2009; 111: 774-8.

47. Kleinschmidt-DeMasters BK, Pflaumer SM, Mulgrew TD, Lillehei KO. Sinonasal teratocarcinosarcoma ("mixed olfactory neuroblastoma-craniopharyngioma") presenting with syndrome of inappropriate secretion of antidiuretic hormone. Clin Neuropathol 2000; 19: 63-9.

48. Sohrabi S, Drabick JJ, Crist H, Goldenberg D, Sheehan JM, Mackley HB. Neoadjuvant concurrent chemoradiation for advanced esthesioneuroblastoma: a case series and review of the literature. J Clin Oncol 2011; 29: e358-61.

49. Kagawa K, Fujitaka K, Isobe T, Yamasaki M, Miyazaki M, Oguri T, Kohno N. Syndrome of inappropriate secretion of ADH (SIADH) following cisplatin administration in a pulmonary adenocarcinoma patient with a malignant pleural effusion. Intern Med 2001; 40: 1020-3.

50. Senchak A, Freeman J, Ruhl D, Senchak J, Klem C. Low-grade esthesioneuroblastoma presenting as SIADH: a review of atypical manifestations. Case Rep Otolaryngol 2012; 2012: 582180.

51. Sutton RA, Schonholzer K, Kassen BO. Transient syndrome of inappropriate antidiuretic hormone secretion during pregnancy. Am J Kidney Dis 1993; 21: 444-5.

52. Renneboog B, Decaux G. Idiopathic hyponatremia in a young patient: look at the sinus. Am J Med 2008; 121: e5-6.

53. Schrier RW. Systemic arterial vasodilation, vasopressin, and vasopressinase in pregnancy. J Am Soc Nephrol 2010; 21: 570-2.

54. Plasencia YL, Cortés MB, Arencibia DM, et al. Esthesioneuroblastoma recurrence presenting as a syndrome of inappropriate antidiuretic hormone secretion. Head Neck 2006; 28: 1142-6.

55. Myers SL, Hardy DA, Wiebe CB, Shiffman J. Olfactory neuroblastoma invading the oral cavity in a patient with inappropriate antid iuretic hormone secretion. Oral Surg Oral Med Oral Pathol 1994 77: 645-50.

56. Müller MB, Landgraf R, Keck ME. Vasopressin, major depression, and hypothalamic-pituitary-adrenocortical desensitization. Biol Psychiatry 2000; 48: 330-3.

57. Fava GA, Sonino N, Morphy MA. Major depression associated with endocrine disease. Psychiatr Dev 1987; 5: 321-48.

58. Frank E, Landgraf R. The vasopressin system - from antidiuresis to psychopathology. Eur J Pharmacol 2008; 583: 226-42.

59. Heuser I, Yassouridis A, Holsboer F. The combined dexametha sone/CRH test: a refined laboratory test for psychiatric disorders. J Psychiatr Res 1994; 28: 341-56.

60. Heuser I. Anna-Monika-Prize paper. The hypothalamic-pituitary-adrenal system in depression. Pharmacopsychiatry 1998; 31: 10-3.

61. Hassan A, Chacko S, Mason D. Desensitization of the adrenocorticotrophin responses to arginine vasopressin and corticotrophin-releasing hormone in ovine anterior pituitary cells. J Endocrinol 2003; 178: 491-501.

62. Tang A, O’Sullivan AJ, Diamond T, Gerard A, Campbell P. Psychiatric symptoms as a clinical presentation of Cushing's syndrome. Ann Gen Psychiatry 2013; 12: 23.

63. Griffith JP. Esthesioneuroblastoma: an unusual cause of frontal lobe dysfunction. W V Med J 1995; 91: 142-3.

64. Dascalu S, Chayen B, Kaplan B, Harel L. Olfactory neuroblastoma as acute postpartum depression. J Am Board Fam Pract 1998; 11 : 414-6.

65. Saghafi D. Water loading test in the reset osmostat variant of SIADH. Am J Med 1993; 95: 343.

66. Gray ST, Holbrook EH, Najm MH, Sadow PM, Curry WT, Lin DT. Syndrome of inappropriate antidiuretic hormone secretion in patients with olfactory neuroblastoma. Otolaryngol Head Neck Surg 2012; 147: 147-51.

67. Gabbay U, Leider-Trejo L, Marshak G, Gabbay M, Fliss DM. A case and a series of published cases of esthesioneuroblastoma (ENB) in which long-standing paraneoplastic SIADH had preceded ENB diagnosis. Ear Nose Throat J 2013; 92: E6.

68. Boursier C, Nottet J-B, Barberot J-P, et al. Syndrome de Schwartz Bartter symptomatique d'esthésioneuroblastome: A propos d'un cas. J Français d'oto-rhino-laryngologie 1999; 48: 391-5.
69. Bernard P, Vitrey D, Boursier C, Brunot J, Fléchaire A. Olfactory esthesioneuroma manifesting as Schwartz-Bartter syndrome. Rev Med Interne 2000; 21: 278-81.

70. Miura K, Mineta H, Yokota N, Tsutsui Y. Olfactory neuroblastoma with epithelial and endocrine differentiation transformed into ganglioneuroma after chemoradiotherapy. Pathol Int 2001; 51: 942-7.

71. Freeman SR, Mitra S, Malik TH, Flanagan P, Selby P. Expression of somatostatin receptors in arginine vasopressin hormone-secreting olfactory neuroblastoma - report of two cases. Rhinology 2005; 43: 61-5.

72. Maeda H, Tsuruya K, Yotsueda H, Taniguchi M, Tokumoto M, Hirakata $\mathrm{H}$, lida $\mathrm{M}$. A case report of syndrome of inappropriate secretion of antidiuretic hormone with marked edema due to administration of hypertonic saline. Ther Apher Dial 2007; 11: 309-13.

73. Perry KM, Heyliger A, Batra PS, Truelson J, Milchgrub S, Saxena R, Chang AY. Recurrent Hyponatremia Due to Reset Osmostat after Resection of an ADH-Secreting Olfactory Neuroblastoma. 2011 [http://edrv.endojournals.org/cgi/content/meeting_abstract/ 32/03_MeetingAbstracts/P3-751].

74. Iliades T, Printza A, Eleftheriades N, Georgios K, Psifidis A, Thomas Z. Olfactory neuroblastoma. A report of 3 cases. ORL J Otorhinolaryngol Relat Spec 2002; 64: 454-6.

75. Verbalis JG. Case study 1: Hyponatremia in SIADH. Clin Perspect Hyponatremia 2012; 3: 8-9.

76. Yang S, Yen C, Hsiao L. Case report long-term remission of advanced esthesioneuroblastoma after chemoradiotherapy. J Cancer Res Pr 2012; 28: 177-82.

77. Cho HC, Park HM, Kim JS, et al. The syndrome of inappropriate antidiuretic hormone secretion with olfactory neuroblastoma: a case report. Korean J Med 2009; 76: S158-S63.

78. Nabili V, St John M, Cohan P, Lufkin R, Bhuta S, Abemayor E. Radiology quiz case 1 . Catecholamine-secreting olfactory neuroblastoma (OFN). Arch Otolaryngol Head Neck Surg 2006; 132: 342, 344-5.

79. Dupuy M, Bonneville F, Grunenwald S, Breibach F, Delisle MB, Chaynes P, Sol JC, Caron P. Primary sellar neuroblastoma. A new case and review of literature. Ann Endocrinol (Paris) 2012; 73: 216-21.

80. Pope TL Jr, Morris JL, Cail WS, Elkon D. Esthesioneuroblastoma presenting as an intracranial mass. South Med J 1980; 73: 643-5.

81. Radotra B, Apostolopoulos V, Sandison A, et al. Primary sellar neuroblastoma presenting with syndrome of inappropriate secretion of anti-diuretic hormone. Endocr Pathol 2010; 21: 266-73.

82. Hoorn EJ, Monserez DA, Fenton RA, Overdevest I, Apperloo AJ, Zietse R, Hardillo JA. Olfactory neuroblastoma with hyponatremia. J Clin Oncol 2014 [Epub ahead of print].

83. Wade PM Jr, Smith RE, Johns ME. Response of esthesioneuroblastoma to chemotherapy. Report of five cases and review of the literature. Cancer 1984; 53: 1036-41.

84. García Vicente A, García Del Castillo E, Soriano Castrejón A, Alonso Farto J. Olfactory esthesioneuroblastoma: scintigraphic expression of somatostatin receptors. Rev Esp Med Nucl 1999; 18: 367-70.

85. Le Guillou C, Schwaab G, Marandas P, Leridant AM, Piekarski JD, Lusinchi A, Micheau C. Olfactory esthesioneuroma. Clinical description and therapeutic results apropos of 45 cases observed at the Gustave Roussy Institute from 1956 to 1986. Ann Otolaryngol Chir Cervicofac 1987; 104: 415-24.

86. Singh W, Ramage C, Best P, Angus B. Nasal neuroblastoma secreting vasopressin. A case report. Cancer 1980; 45: 961-6.

87. Srigley JR, Dayal VS, Gregor RT, Love R, van Nostrand AW. Hyponatremia secondary to olfactory neuroblastoma. Arch Otolaryngol 1983; 109: 559-62.

88. Cullen MJ, Cusack DA, O’Briain DS, Devlin JB, Kehely A, Lyons TA. Neurosecretion of arginine vasopressin by an olfactory neuroblastoma causing reversible syndrome of antidiuresis. Am J Med 1986; 81: 911-6.

89. Osterman J, Calhoun A, Dunham M, et al. Chronic syndrome of inappropriate antidiuretic hormone secretion and hypertension in a patient with olfactory neuroblastoma. Evidence of ectopic production of arginine vasopressin by the tumor. Arch Intern Med 1986; 146: 1731-5.

90.Zuber SM, Kantorovich V, Pacak K. Hypertension in pheochromocytoma: characteristics and treatment. Endocrinol Metab Clin North Am 2011; 40: 295-311. 
91. van Duinen N, Steenvoorden D, Kema IP, et al. Increased urinary excretion of 3-methoxytyramine in patients with head and neck paragangliomas. J Clin Endocrinol Metab 2010; 95: 209-14.

92. Kumar UM, Pande P, Savita S, Pk A, Yelikar BR. An extra-adrenal pheochromocytoma presenting as malignant hypertension a report of two cases. J Clin Diagn Res 2013; 7: 1177-9.

93. Sorensen PH, Wu JK, Berean KW, et al. Olfactory neuroblastoma is a peripheral primitive neuroectodermal tumor related to Ewing sarcoma. Proc Natl Acad Sci U S A 1996; 93: 1038-43.

94. Takahashi H, Wakabayashi K, Ikuta F, Tanimura K. Esthesioneuroblastoma: a nasal catecholamine-producing tumor of neural crest origin. Acta Neuropathol 1988; 76: 522-7.

95. Castañeda VL, Cheah MS, Saldivar VA, Richmond CM, Parmley RT. Cytogenetic and molecular evaluation of clinically aggressive esthesioneuroblastoma. Am J Pediatr Hematol Oncol 1991; 13: 62-70.

96. Micheau C, Guerinot F, Bohuon C, Brugere J. Dopamine-B-hydroxylase and catecholamines in an olfactory esthesioneuroma. Cancer 1975; 35: 1309-12.

97. Hariskov S, Schumann R. Intraoperative management of patients with incidental catecholamine producing tumors: A literature review and analysis. J Anaesthesiol Clin Pharmacol 2013; 29: 41-6.

98. Salmasi V, Schiavi A, Orr B, et al. Intraoperative hypertensive crisis due to a catecholamine-secreting esthesioneuroblastoma. J Neurol Surg Part B Skull Base 2012; 73: A231.

99. Carroll R, Matfin G. Endocrine and metabolic emergencies: hypercalcaemia. Ther Adv Endocrinol Metab 2010; 1: 225-34.

100. Soki FN, Park SI, McCauley LK. The multifaceted actions of PTHrP in skeletal metastasis. Future Oncol 2012; 8: 803-17.

101. Lin JH, Tsai DH, Chiang YH. A primary sellar esthesioneuroblastomas with unusual presentations: a case report and reviews of literatures. Pituitary 2009; 12: 70-5.

102. Skinner DC. Rethinking the stalk effect: a new hypothesis ex plaining suprasellar tumor-induced hyperprolactinemia. Med Hy potheses 2009; 72: 309-10.

103. Dalmau J, Rosenfeld MR. Paraneoplastic syndromes of the CNS Lancet Neurol 2008; 7: 327-40.

104. Raspotnig M, Vedeler CA, Storstein A. Onconeural antibodies in patients with neurological symptoms: detection and clinical significance. Acta Neurol Scand Suppl 2011; 191: 83-8.

105. Stefanowicz J, Izycka-Swieszewska E, Drozyńska E, et al. Neuro blastoma and opsoclonus-myoclonus-ataxia syndrome - clinical and pathological characteristics. Folia Neuropathol 2008; 46: 176 85.

106. Van Diest D, De Raeve H, Claes J, Parizel PM, De Ridder D, Cras P. Paraneoplastic Opsoclonus-Myoclonus-Ataxia (OMA) syndrome in an adult patient with esthesioneuroblastoma. J Neurol 2008; 255: 594-6.

107. Bataller L, Graus F, Saiz A, Vilchez JJ. Clinical outcome in adult onset idiopathic or paraneoplastic opsoclonus-myoclonus. Brain 2001; 124: 437-43.

108. Sugita Y, Kusano K, Tokunaga O, Mineta T, Abe M, Harada H, Shigemori M. Olfactory neuroepithelioma: an immunohistochemical and ultrastructural study. Neuropathology 2006; 26: 400-8.

109. Maeda K, Sasaki T, Murata Y, et al. Paraneoplastic cerebellar degeneration in olfactory neuroepithelioma. J Neurol Neurosurg Psychiatry 2006; 77: 123-4.

\section{Address for correspondence}

Michat Kunc

Medical University of Gdańsk

Smoluchowskiego 17

80-214 Gdansk, Poland

e-mail: mkunc@gumed.edu.pl

Submitted: 8.07.2014

Accepted: 21.07 .2014 